\title{
Paulina Rzewucka
}

(1) https://orcid.org/0000-0002-4095-5544

Uniwersytet Papieski Jana Pawła II w Krakowie

\section{Tożsamość rodziny $z$ dzieckiem} $z$ niepełnosprawnością

\section{w przekazie medialnym}

https://doi.org/10.15633/9788374389839.07

Nauki, w których w centrum zainteresowania znajduje się człowiek m.in. psychologia ${ }^{1}$, socjologia ${ }^{2}$, pedagogika ${ }^{3}$ - podkreślają, iż jest on istotą społeczną. Żyje bowiem w grupie, w której uczy się zasad koegzystencji z innymi, poznaje wartości i tworzy więzi. Niewątpliwe podstawowym miejscem takiej nauki jest rodzina. Jak stwierdza Zbigniew Tyszka: „Rodzina stanowi integralną część każdego społeczeństwa; stanowi jego najmniejszą i podstawową komórkę. Jest najważniejszą grupą społeczną, grupą podstawową, z którą człowiek jest ściśle związany znaczną częścią swojej osobowości i ważnymi pełnionymi przez siebie rolami społecznymi” ${ }^{4}$. W kontekście rozważań dotyczących tożsamości społecznej nie sposób nie odnieść się do rodziny jako grupy funkcjonującej w ramach określonego kontekstu. Rodzina jako grupa jest bowiem częścią większej grupy - całego społeczeństwa. W rodzinie kształtuje się tożsamość każdego z jej członków, ale także tożsamość jej samej. Rodzina z dzieckiem z niepełnosprawnością, jak każda z rodzin, ma swoją wyjątkową tożsamość. Jej członkowie spędzają wspólnie czas, dzielą troski i radości oraz sięgają do mediów, w których być może szukają odzwierciedlenia

\footnotetext{
1 Por. E. Aronson, Człowiek istota spoteczna, Pwn, Warszawa 2009.

2 Por. P. Sztompka, Socjologia. Analiza spoteczeństwa, Wydawnictwo PLus, Kraków 2002.

3 Por. P. Czarnecki, Pedagogika społeczna. Podstawowe pojęcia i definicje, „Społeczeństwo i Edukacja. Międzynarodowe Studia Humanistyczne" (2012) nr 1, s. 389-414.

4 Rodzina, w: Encyklopedia pedagogiczna, red. W. Pomykało, Warszawa 1993, s. 695.
} 
swojej rzeczywistości. Czy ją tam znajdują? Warto zatem poddać analizie zagadnienie poczucia przynależności rodziny z dzieckiem z niepełnosprawnością do społeczeństwa składającego się z innych rodzin i innych grup, a także sprawdzić, w jaki sposób - i czy w ogóle - jest ona przedstawiana $\mathrm{w}$ mediach.

\section{Tożsamość społeczna rodziny. Rola mediów}

Jak zauważa Izabela Gątarek: „Tożsamość człowieka, czyli jego wyobrażenie o sobie samym, jest niejako percepcyjną soczewką, okularami, przez które postrzega otaczający go świat i samego siebie"5. Podobnie można interpretować tożsamość rodziny - jako postrzeganie jej samej przez jej członków w odniesieniu do otaczającego ją świata. Rodzina ma potrzebę przynależności do społeczeństwa. Wynika ona z podstawowych potrzeb człowieka, opisywanych przez Abrahama Maslowa ${ }^{6}$. Tak więc rodzina chce niejako „wpasować się” w społeczeństwo, w którym żyje, chce przynależeć do niego, być jego aktywnym członkiem. Skąd zatem bierze ona informacje o tym, jak wyglądają i funkcjonują inne rodziny? Kiedy uznaje, że „pasuje” bądź nie do społeczeństwa?

Rodzina tworzy grupę, która wchodzi w relacje $\mathrm{z}$ innymi grupami, $\mathrm{w}$ tym $\mathrm{z}$ innymi rodzinami. Chce ona być akceptowana i uczestniczyć czynnie w życiu społecznym. Jak zauważają Renata i Grzegorz Gałuszka: „Dziecko niepełnosprawne wprowadza szereg nieprzewidzianych wcześniej zmian w swojej rodzinie, w psychice każdego z jej członków, w relacjach między nimi, w funkcjonowaniu społecznym rodziny, jej sytuacji materialnej. Problemem jest nie tylko choroba dziecka, ale i nowa, złożona sytuacja rodziny. Rodzice, rodzeństwo, bliżsi i dalsi krewni są zmuszeni do zmiany sposobu życia, swoich postaw i zachowań”7. W tej nowej, trudnej sytuacji rodzina $\mathrm{z}$ dzieckiem $\mathrm{z}$ niepełnosprawnością często na nowo poszukuje poczucia przynależności do społeczeństwa. Może to wynikać

\footnotetext{
5 I. Gątarek, Kim jestem? Czyli o ksztattowaniu tożsamości dziecka, „Seminare” 37 (2016) nr 1, s. 105.

6 Por. A. Maslow, Motywacja i osobowość, Pwn, Warszawa 2009, s. 62-76.

7 G. Gałuszka, R. Gałuszka, Jakość życia rodziny niepetnosprawnego dziecka zamieszkującej w'środowisku wiejskim, „Zdrowie i Dobrostan” (2015), nr 2, s. 110.
} 
z odmiennej względem innych rodzin sytuacji, związanej z chorobą dziecka. Świadomość tego, że nie jest się wyalienowanym z otoczenia, mogą wzmacniać rożne grupy wsparcia. Składają się one $z$ innych rodzin, które znalazły się w podobnym położeniu. Rodzin, które są w stanie zrozumieć kontekst problemów, z którymi przyszło się zmierzyć w nowej sytuacji. $\mathrm{Na}$ stronie internetowej jednej z takich grup, działającej przy stowarzyszeniu Dać Pomoc, można przeczytać, iż za główne cele pracy obiera „dzielenie się doświadczeniem w celu pokonywania trudności, dzielenie się wsparciem emocjonalnym, zwalczanie bezradności wobec problemu, choroby, trudnej sytuacji życiowej, budowanie siły, nadziei, i poczucia wartości wśród uczestników, wymianę użytecznych informacji, szukanie wspólnymi siłami rozwiązań”.

Kopalnią informacji o tym, jak wyglądają i funkcjonują inne rodziny, okazać mogą się także media. Jak zaznacza Anna Gębalska-Berekets: „Niezaprzeczalnym pozostaje fakt, iż ludzie korzystają z doświadczeń medialnych pozyskują informacje, które mają zasadniczy wpływ na kształtowanie ich własnego «ja» oraz sposób postrzegania rzeczywistości. Ten fakt potwierdzają liczne badania. Percepcja człowieka, w znacznej mierze nastawiona jest na wizualny sposób postrzegania"9. Rola mediów w kształtowaniu obrazu rodziny jest niepodważalna. To w nich rodzina szuka prawdy o tym, jaka powinna lub nie powinna być. Jak podaje Michał Dróżdż: „Dążąc do poznania prawdy, człowiek szuka zarówno tej prawdy, która dotyczy prozaicznej rzeczywistości dnia codziennego, przedstawianej przez media, jak i pełni prawdy, bardziej lub mniej odzwierciedlanej w przekazach medialnych, gdyż każda prawda ma charakter uniwersalny"10. Andrzej Turek z kolei zauważa: „Zważywszy na siłę oddziaływania mediów - zwłaszcza telewizji - można rzec, iż telenowele czy programy familijne zawierające pewien model rodziny i ukazujące styl jego realizacji, dla wielu odbiorców stają się wzorcami do naśladowania"11. Media wskazują

8 Stowarzyszenie Dać Pomoc, http://dacpomoc.pl/Grupa-wsparcia.html (2.02.2020).

9 A. Gębalska-Berekets, Znaczenie i rola mediów we wspótczesnej edukacji społeczeństwa informacyjnego, w: Media wedukacji. Wymiar kulturowy i aksjologiczny, red. A. Rogulska, Fundacja na rzecz dzieci i młodzieży „SZANSA”, Siedlce 2013, s. 86.

10 M. Dróżdż, Aksjologiczne uwarunkowania prawdy, w: Prawdaw mediach. Międzyideatem a iluzją?, red. M. Dróżdż, Wydawnictwo Biblos, Tarnów 2010, s. 16.

11 A. Turek, Media w rodzinie - rodzina w mediach. Wzajemne relacje w aspekcie etycznym, $\mathrm{w}$ : Rodzina między praca a płacą: refleksja nad spoteczna myśla encykliki „Laborem exercens” 
pożądany model zachowań. W badaniach Agaty Opolskiej - Bielańskiej dotyczących m.in. samooceny wpływu mediów na respondentów, 74,1\% nastolatków w wieku 14-16 lat (w badaniach uczestniczyło 526 nastolatków) oceniło, iż media mają na nich istotny wpływ ${ }^{12}$. Telewizja i Internet kreują pewną wizję świata, którą być może zupełnie nieświadomie odbiorca przyjmuje i uznaje za swoją. Jak pisze Zbyszko Melosik: „Telewizja i Internet nie stanowią już „lustra”, odzwierciedlającego społeczeństwo; jest odwrotnie, to życie społeczne staje się imitacją rzeczywistości ekranu"13.

Rodzina jako środowisko życia człowieka przedstawiana jest w reklamie, serialach czy filmach. W niniejszym opracowaniu uwaga zostaje skupiona na wybranych przez autorkę krótkich przekazach medialnych, które w szybki i łatwy sposób mają trafić do jak największej liczby odbiorców. Zaprezentowany przegląd zawiera przykłady stanowiące wycinek ogromnego rynku reklam oraz krótkometrażowych seriali, w których pojawia się rodzina, przedstawiana w różnych kontekstach.

Warto podkreślić, iż każde z mediów ma prawo do ukazania rodziny w wybrany przez siebie sposób. Najczęściej jest to taki, który trafi do jak największej grupy odbiorców i przyniesie zakładany zysk. W reklamach, co wynika chociażby z badań Jerzego Widerskiego ${ }^{14}$, rodzina bardzo często ukazywana jest jako szczęśliwa grupa ludzi, często spożywająca wspólnie posiłek, nierzadko przygotowywany przez kobietę jako tę, która opiekuje się gospodarstwem domowym. Przykładem może być reklama produktów ułatwiających gotowanie, np. mieszanek przypraw, które kobieta kupuje w sklepie za namową koleżanki. „Nie masz pomysłu na obiad? Kup go”. W taki sposób gospodyni wraca do domu i w krótkim czasie, z pomocą córki, przygotowuje posiłek dla swojej czteroosobowej rodziny, posiłek, który chwali parter/mąż $\dot{z}^{15}$. Jerzy Widerski w analizie reklam wskazuje

Jana Pawła II, red. R. Kantor, M. Kluz, J. Młyński, Wydawnictwo Naukowe Uniwersytetu Papieskiego Jana Pawła II, Kraków 2016, s. 230.

12 A. Opolska-Bielańska, Nastolatek $w$ mediach, w: Recepcja mediów przez młodzież $i$ osoby dorosłe, Wydawnictwo Uniwersytetu Marii Curie-Skłodowskiej, red. B. Boniecka, A. Granat, Lublin 2018, s. 39-53.

13 Z. Melosik, Edukacja, młodzieżi kultura wspótczesna. Kilka uwago praktycepedagogicznej, Katowice 2003, s. 23.

14 Por. J. Widerski, Modele rodziny w reklamach telewizyjnych. Analiza semiotyczna, „Opuscula Sociologica" (2018) nr 23, s. 87-88.

15 Reklama mieszanki przypraw, https://www.youtube.com/watch?v=2ugs7vs 7 Udo (2.01.2020). 
także na małżeństwa egalitarne „w spotach tych wyraźnie widać, że dla obojga małżonków dom nie jest jedynym miejscem samorealizacji i każda ze stron ma autonomię. Do tej grupy także należą reklamy produktów spożywczych, a wspólne spożywanie posiłków jest ważną ceremonią"16. Rodziny w reklamie nie borykają się z problemami. Jeśli pojawi się mała niedogodność, zostaje ona całkowicie wyeliminowana. Przykładem może być reklama leku na katar, w której kobieta „ratuje” swojego partnera odpowiednim preparatem, gdyż ich związek „dopadł męski katar”" ${ }^{\text {17 }}$. Warto dodać, iż obraz ten epatuje różnymi stereotypami, np. przeżywanie przez mężczyznę choroby i jej skutki dla związku.

Do rodziny - jako głównego bohatera - sięga się także w serialach. W nich także obserwuje się wielość przykładów obecnego życia rodzinnego. Krótka syntezę przedstawia Andrzej Turek: „Obraz rodziny w mediach opalizuje skrajnościami. Seriale i telenowele pozwalają tutaj zauważyć wyraźną dwubiegunowość. Z jednej strony mamy więc Klan (nomen omen) - a nim rodzinę rozbudowaną, «autentyczną», wielopokoleniową, a z drugiej niepełną w wielu konotacjach i znaczeniach tego słowa, a więc: małżonków bezdzietnych, matki czy ojców samotnie wychowujących dzieci czy wreszcie rodziny życiowo dowcipne (Rodzinka.pl), skąpane w konwencji sitcomowego żartu (Miodowe lata) albo wyraźnie tragikomiczne, ocierające się o patologiczną groteskę (Światwedtug Kiepskich)"18. Oprócz przykładów zaczerpniętych z polskiej telewizji, warto sięgnąć także do tych, które biją rekordy popularności w Stanach Zjednoczonych ${ }^{19}$. Modern family to amerykański serial komediowy przedstawiający losy głównego bohatera, który po śmierci swojej żony związał się z dużo młodszą od siebie kobietą oraz losy jego dwójki dzieci - córki, która wraz mężem wychowuje trójkę dzieci, oraz syna, który jest w związku z mężczyzną, i razem z nim wychowuje adoptowaną córkę. Tytułowe współczesne rodziny przeżywają różne trudności dnia codziennego, a całość jest przedstawiona łatwy w odbiorze i przyjemny dla widza sposób. Serial jest tak-

16 J. Widerski, Modele rodziny..., dz. cyt. s. 88.

17 Reklama leku na katar, https://www.youtube.com/watch?v=oMxlyUohluU (2.01.2020).

18 A. Turek, Media w rodzinie, dz. cyt., s. 229.

19 Portale oceniające popularność seriali, wskazują, iż Modern Family ogląda w usa około 10 milionów widzów tygodniowo, https://fortune.com/2019/02/05/modern-family-ending-finale-cast-final-season/ (2.01.2020). 
że od 2010 roku emitowany w Polsce. Ponownie odnosząc się do mediów jako prezentera pewnych wzorców godnych naśladowania, należy przedstawiony obraz skonfrontować z rzeczywistością, w której młodzi ludzie poprzez przekaz medialny kształtują swoje wyobrażenie o współczesnej rodzinie. Papież Franciszek w Orędziu na Światowy Dzień Środków Społecznego Przekazu w 2015 roku zaznaczył: „Media niekiedy mają tendencję do takiego przedstawiania rodziny, jakby to był abstrakcyjny model do przyjęcia lub odrzucenia, do obrony lub atakowania, a nie konkretna rzeczywistość, w której się żyje; albo jakby była czyjąś ideologią przeciwko ideologii kogoś innego, a nie miejscem, w którym wszyscy uczymy się, co to znaczy porozumiewać się w miłości otrzymywanej i dawanej”20. $\mathrm{W}$ tych słowach wyraził on troskę o obraz rodziny w mediach, ale także podkreślił, iż nie zawsze to, co ukazane jest w środkach masowego przekazu, ma odzwierciedlenie w rzeczywistości lub pokazuje, jak ta rzeczywistość powinna wyglądać.

\section{Rodzina $z$ dzieckiem $z$ niepełnosprawnością w mediach. Obraz niepełnosprawności w kulturze}

Paulina Gajdziszewska-Dudek i Justyna Stańczyk także zwracają uwagę na pewną iluzję przekazu medialnego dotyczącego rodziny: „Wizerunek rodziny kreowany w mediach tworzy iluzoryczne wrażenie bezproblemowości i łatwości w prowadzeniu domu, wychowaniu dzieci czy utrzymaniu dobrych relacji z partnerem. Sielankowa medialna rzeczywistość może prowadzić do poczucia frustracji i niezadowolenia z własnego życia rodzinnego, jeśli nie wpisuje się ono w kanon rodziny prezentowany w mediach"21. W kontekście występowania pewnego mirażu rzeczywistości rodzinnej w środkach masowego przekazu swojej tożsamości szuka także rodzina $\mathrm{z}$ dzieckiem $\mathrm{z}$ niepełnosprawnością.

20 Orędzie papieża Franciszka na XLıx Światowy Dzień Środków Społecznego Przekazu.

Przekaz o rodzinie jako uprzywilejowanym miejscu spotkania w bezinteresownej miłości, http://www.vatican.va/content/francesco/pl/messages/communications/documents/papafrancesco_20150123_messaggio-comunicazioni-sociali.html (2.01.2020).

21 P. Gajdziszewska - Dudek, J. Stańczyk, Rodzina a media. O sile wptywu wspótczesnych mass mediów na przeksztatcenia roli i funkcji rodziny, „Zeszyty Naukowe Towarzystwa Doktorantów UJ. Nauki Społeczne" (2015) nr 10, s. 142. 
Pojawienie się w rodzinie potomstwa związane jest ze zmianą dotychczasowego trybu życia. Jest to czas oczekiwania i snucia planów na przyszłość. Przełomowy jest jednak moment, w którym rodzice dowiadują się o niepełnosprawności swojego wyczekiwanego dziecka ${ }^{22}$. Jest to czas, o którym często mówi się, używając stwierdzenia „ewolucja przeżyć emocjonalnych"23. Zmieniają się także relacje z najbliższymi. Jak zauważają Grzegorz Godawa i Katarzyna Kutek-Sładek: „W rodzinie skonfrontowanej z sytuacją niepełnosprawności dziecka system rodzinny zostaje obciążony dodatkowymi trudnościami, które wpływają na funkcjonowanie poszczególnych jej członków”24. Rodzina musi odnaleźć się w nowej, trudnej rzeczywistości, a także na nowo zdefiniować swoją tożsamość. Agnieszka Suchocka i Iwona Królikowska zwracają uwagę, że: „Zbiorowa tożsamość to poczucie odmienności grupy, do której należymy, jej szczególnych cech i systemu wartości, jaki wyznaje. To poczucie wzmacnia grupę, przyczynia się do jej trwania w czasie”25. Niepełnoprawność dziecka $\mathrm{w}$ rodzinie sprawia, iż jest ona już odmienna od innych. Nie jest to jednak powód do stygmatyzacji, gdyż w gruncie rzeczy każda rodzina, niezależnie od tego, czy występuje w niej niepełnosprawność, czy też nie, różni się sposobami spędzania czasu, relacjami, klimatem w niej panującym. W tym momencie rodzi się zatem pytanie: skoro każda rodzina jest unikalna, to dlaczego nie każda pojawia się w mediach, a przedstawiane są w nich jedynie wybrane jej modele?

Analiza seriali czy reklam dokonana wcześniej właściwie pozbawiona jest przykładów obrazów rodzin z dzieckiem z niepełnosprawnością. Krótki obraz trafiający do odbiorcy, zaledwie kilkadziesiąt sekund w reklamach lub kilkanaście minut w serialach, ma przede wszystkim sprawić, by w przypadku reklamy - potencjalny klient zakupił produkt lub - w przy-

22 M. Białas, Proces inkluzji dziecka niepetnosprawnego w rodzinie z pozycji interpretacji wartości solidarności w ujęciu Jana Pawła II, „Rozprawy Społeczne” 9 (2015) nr 4, s. 23-28.

23 A. Twardowski, Rodzina a dziecko niepetnosprawne, w: Dziecko niepetnosprawne w rodzinie, red. I. Obuchowska, Wydawnictwo Szkolne i Pedagogiczne, Warszawa 1991, s. 18-34.

24 G. Godawa, K. Kutek-Sładek, Dialog w rodzinie dziecka z niepetnosprawnościa - krytyczna ocena funkcjonowania $w$ dziecinstwie opinii niepetnosprawnych studentów, „Wychowanie w Rodzinie" xI (2015), s. 364.

25 A. Suchocka, I. Królikowska, Kreowanie tożsamości kulturowej jako wyzwanie XXI wieku, "Colloquium Wydziału Nauk Humanistycznych i społecznych Kwartalnik” (2014) nr 4, s. 76 . 
padku serialu - odbiorca miło spędził czas, tym samym zainwestował swój czas w dalsze oglądanie, zwiększając oglądalność produkcji. Agencje zajmujące się public relations czynią przekaz maksymalnie uatrakcyjniony ${ }^{26}$. Być może obraz inności, takiej, która nie jest obecna w szerokim znaczeniu w popkulturze, jest wygodny w alienacji. Ciekawym zjawiskiem jest pojawienie się w przestrzeni reklam czy seriali np. grup LGBTQ, choć stanowią one relatywnie niższy procent udziału społeczeństwa niż rodziny, w których występuje niepełnosprawność. Dziennik ekonomiczno-prawny „Rzeczpospolita”, powołując się na niemieckie badania, podaje, iż mniejszości seksualne stanowią 4,9\% polskiego społeczeństwa ${ }^{27}$. Z kolei według Narodowego Spisu Powszechnego Ludności i Mieszkań z 2011 roku wynika, iż 12,2\% osób żyjących w Polsce stanowią osoby z niepełnosprawnością ${ }^{28}$. Z kolei w Stanach Zjednoczonych grupa LGBTQ stanowi 3,5\% społeczeństwa $^{29}$, z kolei osoby z niepełnosprawnościami $12,8 \%{ }^{30}$.

W reklamach telewizyjnych rodzina $\mathrm{z}$ dzieckiem $\mathrm{z}$ niepełnosprawnością przedstawiana jest jedynie w kontekście pomocowym, a zatem w reklamach fundacji pomagającym dzieciom. Przykładem mogą być reklamy, w których na pierwszy plan wysuwa się dziecko z niepełnosprawnością, natomiast rodzice są tłem ${ }^{31}$. Mają one na celu przekonać odbiorcę do wsparcia finansowego leczenia. Brakuje reklam przedstawiających rodzinę przy wspólnym posiłku lub spędzających czas na zakupach. Wydaje się, że cierpienia, trudy, a także niekoniecznie smutna codzienność rodzin z dzieckiem z niepełnosprawnym nie są wystarczająco medialne. W tym miejscu warto zauważyć, iż rynek zaczyna dostrzegać niepełnosprawność, choć na razie w kontekście konkretnej osoby, której ona dotyka. Portal „Dzieci są ważne” przedstawia kilka kampanii reklamowych, w których

26 Por. K. Starzyńska, Charakterystyka reklamy w oparciu o jej genezę i cechy, „Zeszyty Naukowe Uniwersytetu Przyrodniczo-Humanistycznego w Siedlcach" (2015) nr 106, s. 277-279.

27 „Rzeczpospolita”, https://www.rp.pl/Spoleczenstwo/312019867-Niemcy-policzyli-gejow-i-lesbijki-w-Polsce.html (3.01.2020).

28 Biuro Pełnomocnika Rządu ds. Osób Niepełnosprawnych, http://www.niepelnosprawni. gov.pl/index.php?c=page\&id=78 (3.01.2020).

29 Gary J. Gates, Williams Distinguished Scholar, How many people are lesbian, gay, bisexual, and transgender?, http://williamsinstitute.law.ucla.edu/wp-content/uploads/Gates-How-Many-People-LGBT-Apr-20II.pdf (2.0I.2020).

30 Disability Statistics Annual Report, https://disabilitycompendium.org/sites/default/files/ user-uploads/2017_AnnualReport_2017_FINAL.pdf (2.01.2020).

31 Reklama fundacji, https://www.youtube.com/watch?v=HePADT5Oakk (3.01.2020). 
dzieci z niepełnosprawnością są modelami prezentującymi ubrania. Autorzy sami zwracają jednak uwagę na niewystarczające zainteresowanie telewizji niepełnosprawnością - w takiej formie, by była ona uznana za „normalność" 32 .

W serialach rodzina $\mathrm{z}$ dzieckiem $\mathrm{z}$ niepełnosprawnością przedstawiana jest także w kontekście pomocowym. Epizodyczne sceny pojawiają się w serialach o tematyce medycznej (np. Na dobre i na złe lub amerykański serial Chirurdzy). W Polsce serial Klan jest jednym z niewielu, w którym pojawia się postać dziecka $\mathrm{z}$ niepełnosprawnością. Jest to jednak jedynie wycinek szerokiej fabuły. Stąd też przełomowym w tym aspekcie był amerykański serial Speechless, emitowany w latach 2016-2019. Komediowa fabuła skupia się na codzienności małżeństwa wychowującego trójkę dzieci, w tym syna chorującego na porażenie mózgowe, który komunikuje się za pomocą nakrycia głowy ze wskaźnikiem laserowym, aby wskazać różne słowa, litery i cyfry na tablicy przymocowanej do wózka inwalidzkiego. Każdy członek rodziny ma inną osobowość, a sceny życia rodzinnego przedstawiają codzienne sytuacje, zarówno te wzruszające, jak i zabawne oraz niezwykle trudne. Krytycy rozrywki bardzo pozytywnie przyjęli serial. Świadczą o tym wypowiedzi na portalu skupiającym recenzje wytworów rozrywki: „Speechless jest gryząco zabawny i jest także rzadkim przypadkiem, w którym można opowiedzieć historię niepełnosprawnego bohatera i jego rodziny bez przygnębienia i litości”33. Inna wypowiedź: „Speechless podejmuje ryzyko związane z tematem często uważanym za tabu i - jak dotąd - zapewnia urzekający show"34. Serial na pewno daje początek nowej, choć społecznie dobrze znanej tematyce. Przełamuje także wspomniane przez krytyków tabu, demaskując niedościgniony wzorzec rodziny przedstawiany w mediach.

Warto dodać, iż w mediach znacznie częściej (choć i tak za rzadko) pojawia się temat niepełnosprawności pozbawiony kontekstu rodzinnego. Za przykład służą głównie kampanie społeczne podkreślające istotę

32 Portal Dzieci są ważne, https://dziecisawazne.pl/rodzic-dziecka-niepelnosprawnego-widzi-wiecej/ (3.01.2020).

33 Portal z recenzjami rozrywki „Rottentomatoes”, https://www.rottentomatoes.com/tv/ speechless/so1/reviews (3.01.2020).

34 Portal z recenzjami rozrywki „Rottentomatoes”, https://www.rottentomatoes.com/tv/ speechless/so1/reviews (3.01.2020). 
włączania wszystkich osób z niepełnosprawnościami, nie tylko dzieci, do aktywnego uczestnictwa w społeczeństwie. W 2016 roku z okazji Międzynarodowego Dnia Głuchych niektóre stacje telewizyjne zaprezentowały serwis informacyjny, w którym osoby z dysfunkcją słuchu przedstawiały wiadomości, używając języka migowego ${ }^{35}$. Polski Związek Głuchych, który zorganizował akcje „Polska zmienia się w słuch”, chciał w ten sposób przybliżyć odbiorcom realną możliwość włączenia osób z niepełnosprawnością w środowisko mediów. Kolejnym przykładem jest kampania „Nie chcę być strażakiem”, przygotowana przez Fundację „Integracja”. Ma ona służyć zmianie postaw społecznych dotyczących zatrudniania osób z niepełnosprawnościami. Bohaterowie spotu reklamowego pokazują, iż nie chcą wykonywać wszystkich zawodów, np. strażaka, ale są w stanie odnaleźć się na rynku pracy zgodnie ze swoimi umiejętnościami i predyspozycjami $^{36}$. Inny kontekst nakreśla zaś Fundacja dla dzieci i dorosłych z autyzmem „Synapsis”. W kampanii społecznej „Autyzm wprowadza zmysły w błąd” aktor stara się pokazać, jak osoba z autyzmem odbiera dźwięki i bodźce, które do niej docierają każdego dnia. Spot kończy wypowiedź aktora: „Dla mnie to było zadanie aktorskie, a dla wielu ludzi to codzienność, z którą muszą się zmagać”37. Kampania ma przybliżyć temat autyzmu jej odbiorcom ${ }^{38}$.

Jak już wspomniano, tematyka medialnego obrazu osób z niepełnosprawnościami wciąż jednak wydaje się niewystarczająco często podejmowana. Jak zauważa Monika Struck-Peregończyk: „Mimo, iż osoby niepełnosprawne stanowią kilkanaście procent społeczeństwa, rzadko można je dostrzec w masowych mediach - prasie, telewizji, radiu. Jeśli już się w nich pojawiają, występują przeważnie w programach, filmach i artykułach prasowych poświęconych niepełnosprawności - co sugeruje, że to niepełnosprawność jest dominującą cechą danej osoby. Wciąż brakuje informacji o osobach niepełnosprawnych w programach czy artykułach o szerokiej tematyce, brakuje niepełnosprawnych prezenterów czy gospodarzy pro-

35 Serwis informacyjny - kampania z okazji Międzynarodowego Dnia Głuchych, https:// szczecin.tvp.pl/27081774/1830-250916 (3.01.2020).

36 Kampania „Nie chcę być strażakiem”, https://www.integracja.org/zmieniamy-swiadomosc/kampanie-spoleczne/nie-chce-byc-strazakiem/ (3.01.2020).

Kampania społeczna „Autyzm wprowadza zmysły w błąd”, https://www.youtube.com/ watch?v=2vhqJrEE5_g (3.01.2020).

38 Fundacja dla dzieci i dorosłych z autyzmem „Synapsis”, http://synapsis.org.pl/ (3.01.2020). 
gramów, nawet role osób niepełnosprawnych w filmach grają najczęściej osoby pełnosprawne" ${ }^{39}$. Wydaje się, iż w podobnej sytuacji znajduje się rodzina, której dotyczy niniejsze opracowanie. Jej brak w przestrzeni medialnej potwierdzają podane wcześniej przykłady. Struck-Pergończyk zwraca także uwagę na wizerunek niepełnosprawności w kulturze: „Tradycyjne jest przedstawienie niepełnosprawności jako tragedii osobistej, a ludzi niepełnosprawnych jako niesamodzielnych, potrzebujących pomocy, wiodących smutne, naznaczone samotnością i cierpieniem życie. Taki przekaz trafia już do najmłodszych - w bajkach piękno staje się nie tylko kategorią etyczną, ale także estetyczną - dobre postacie są piękne, zaś złe - brzydkie i ułomne. Osoby niepełnosprawne to zatem często postacie złe i brzydkie, a przynajmniej nieszczęśliwe (np. Quasimodo)"40. Obraz osoby $\mathrm{z}$ niepełnosprawnością $\mathrm{w}$ kulturze warunkuje zatem przedstawianie jej w kontekście rodzinnym. Skoro niepełnosprawność jako trudna i mało atrakcyjna sytuacja życiowa nie jest przedmiotem zainteresowania mediów, nie będzie nią także tło rodzinne.

\section{Podsumowanie}

Przedstawiona analiza tożsamości społecznej rodziny z dzieckiem z niepełnosprawnością $\mathrm{w}$ mediach $\mathrm{z}$ pewnością nie jest wystarczająca. Rysuje ona jedynie występowanie pewnego medialnego tabu związanego z obrazem rodziny, w której niepełnosprawność występuje. Rozważania wskazują jednak, iż należałoby poddać dalszej analizie oraz badaniom wskazany temat. Tożsamość społeczna rodziny nie jest jedynie kwestią, która dotyczy jej samej. Jak pisze Anthony Giddens: „Zmagając się z najbardziej prywatnymi problemami, poszczególne jednostki czynnie odtwarzają otaczający je świat życia społecznego" ${ }^{41}$.

39 M. Struck-Peregończyk, Wizerunek osób niepetnosprawnych w środkach masowego przekazu - zarys zjawiska, „Kwartalnik Internetowy Komunikacja Społeczna” (2013) nr 4 (8), s. 24 .

40 M. Struck-Peregończyk, Wizerunek osób niepetnosprawnych..., dz. cyt., s. 24.

41 A. Giddens, Nowoczesność i tożsamość. „Ja” i spoteczeństwo w epoce późnej nowoczesności, PWN, Warszawa 2001, s. 18. 
Pomimo ukazujących się obrazów medialnych z rodziną w roli głównej oraz podejmowania tematyki niepełnosprawności wciąż obserwowalny jest pewien niedosyt i niedopowiedzenia. Świadczy o tym także niewielka liczba przedstawionych przykładów obrazu rodziny z dzieckiem z niepełnosprawnością w mediach. „Każdej zatem rodzinie wychowującej dziecko niepełnosprawne, nawet najbardziej spójnej wewnętrznie, zintegrowanej emocjonalnie, niezbędne jest wsparcie społeczne" ${ }^{42}$. Wsparcie, które mogą dawać także media. Nie poprzez wykluczanie, ale dawanie jasnego sygnału, iż rodzina z dzieckiem z niepełnosprawnością funkcjonuje w społeczeństwie, powinno się ją akceptować i wspomagać. Pomimo swojej odmienności, która także buduje jej osobistą tożsamość, należy się zarówno jej samej, jak i jej członkom szacunek i prawo do udziału we wszystkich elementach życia społecznego, także w mediach. Jak pisze Tadeusz Borutka: „Poszanowanie praw to budzenie świadomości, że drugi człowiek jest bratem, mimo wstępujących różnic. Bez obudzenia świadomości powszechnego braterstwa i odpowiedzialności za drugiego człowieka, wysiłki zmierzające do ochrony praw nie będą w pełni skuteczne"43. Tworząc jedno społeczeństwo złożone $\mathrm{z}$ różnych grup, rodzina $\mathrm{z}$ dzieckiem $\mathrm{z}$ niepełnosprawnością nie zasługuje na maskowanie w mediach jej funkcjonowania. Rolą środków masowego przekazu, ale także całego społeczeństwa, jest bowiem włączanie jej do aktywnego udziału we wszystkich obszarach życia społecznego.

\section{Abstrakt}

Tożsamość rodziny z dzieckiem z niepetnosprawnościa $w$ przekazie medialnym

Rodzina z dzieckiem z niepełnosprawnością posiada swoją unikalną tożsamość społeczną. Na jej kształtowanie oddziałują także media. Warto zatem zastanowić się, jak środki masowego przekazu ukazują rodzinę i wy-

42 D. Otapowicz, A. Sakowicz-Boboryko, D. Wyrzykowska-Koda, Niepetnosprawność a jakość życia rodziny, „Pogranicze. Studia Społeczne” xxviII (2016), s. 102.

43 T. Borutka, Prawa Osoby Ludzkiej Podstawa Życia Społecznego w Świetle Nauczania Kościoła, Wydawnictwo Naukowe PAT, Kraków 20oo, s. 136. 
stępującą w niej niepełnosprawność. Szczególnej analizie poddane zostają reklamy telewizyjne i seriale, które w krótkim czasie manifestują wycinki obrazów, które rzekomo przedstawiają powszechną rzeczywistość odbiorców. Niniejszy artykuł stanowi próbę wzbudzenia refleksji dotyczących przekazu medialnego w kontekście tak ważnej grupy społecznej, jaką jest rodzina, oraz tak istotnej kwestii, jaką jest niepełnosprawność w niej występująca.

Słowa kluczowe: tożsamość społeczna, rodzina, media, niepełnosprawność

\section{Abstract}

Social identity of a family with a child with a disability in the media

A family with a child with a disability has its own unique social identity. It is also shaped by the media. It is therefore worth considering how today's mass media show the family and the disability that exists in it. TV commercials and series, which in a short period of time present sections of images that allegedly represent the common reality of the audience, are subject to special analysis. This article is an attempt to stimulate reflection on media coverage in the context of such an important social group as the family and its members with disabilities.

Keywords: social identity, family, media, disability

\section{Bibliografia}

Aronson E., Cztowiek istota społeczna, Pwn, Warszawa 2009.

Białas M., Proces inkluzji dziecka niepetnosprawnego $w$ rodzinie z pozycji interpretacji wartości solidarności w ujęciu Jana Pawła II, „Rozprawy Społeczne" 9 (2015) nr 4, s. 23-28.

Biuro Pełnomocnika Rządu ds. Osób Niepełnosprawnych, http://www.niepelnosprawni.gov.pl/index.php?c=page\&id=78 (3.01.2020). 
Borutka T., Prawa Osoby Ludzkiej Podstawa Życia Społecznego w Świetle Nauczania Kościoła, Wydawnictwo Naukowe PAT, Kraków 2000.

Czarnecki P., Pedagogika społeczna. Podstawowe pojęcia i definicje, „Społeczeństwo i Edukacja. Międzynarodowe Studia Humanistyczne" (2012) nr 1, s. 389-414.

Disability Statistics Annual Report, https://disabilitycompendium.org/sites/default/files/user-uploads/2017_AnnualReport_2017_FINAL.pdf (2.01.2020).

Dróżdż M., Aksjologiczne uwarunkowania prawdy, w: Prawda w mediach. Między ideałem a iluzją?, red. M. Dróżdż, Wydawnictwo Biblos, Tarnów 2010.

Fundacja dla dzieci i dorosłych z autyzmem „Synapsis”, http://synapsis.org. $\mathrm{pl} /(3.01 .2020)$.

Gajdziszewska-Dudek P., Stańczyk J., Rodzina a media. O sile wptywu wspótczesnych mass mediów na przeksztatcenia roli i funkcji rodziny, „Zeszyty Naukowe Towarzystwa Doktorantów UJ. Nauki Społeczne” (2015) nr 10, s. $137-148$.

Gałuszka, R., Gałuszka G., Jakość życia rodziny niepetnosprawnego dziecka zamieszkującej w środowisku wiejskim, „Zdrowie i Dobrostan” (2015) nr 2, s. 109-120.

Gary J. Gates, Williams Distinguished Scholar, How many people are lesbian, gay, bisexual, and transgender? http://williamsinstitute.law.ucla. edu/wp-content/uploads/Gates-How-Many-People-LGBT-Apr-2011.pdf (2.01.2020).

Gątarek I., Kim jestem? Czyli o ksztattowaniu tożsamości dziecka, „Seminare” 37 (2016) nr 1, s. 105-116.

Gębalska-Berekets A., Znaczenie i rola mediów we wspótczesnej edukacji spoteczeństwa informacyjnego, w: Media w edukacji. Wymiar kulturowy i aksjologiczny, red. A. Roguska, Fundacja na rzecz dzieci i młodzieży „SzANSA", Siedlce 2013.

Giddens A., Nowoczesność i tożsamość. „Ja” i społeczeństwo w epoce późnej nowoczesności, PWn, Warszawa 2001.

Godawa G., Kutek-Sładek K., Dialog w rodzinie dziecka z niepetnosprawnościa - krytyczna ocena funkcjonowania w dziecinstwie opinii niepetnosprawnych studentów, „Wychowanie w Rodzinie” XI (2015) nr 1, s. 359-376. 
Kampania „Nie chcę być strażakiem” https://www.integracja.org/zmieniamy-swiadomosc/kampanie-spoleczne/nie-chce-byc-strazakiem/ (3.01.2020).

Kampania społeczna „Autyzm wprowadza zmysły w błąd” https://www.youtube.com/watch?v=2vhqJreE5_g (3.01.2020).

M. Struck- Peregończyk, Wizerunek osób niepetnosprawnych w środkach masowego przekazu - zarys zjawiska, „Kwartalnik Internetowy Komunikacja Społeczna" (2013) nr 4 (8), s. 22-32.

Maslow A., Motywacja i osobowość, PWn, Warszawa 2009.

Melosik Z., Edukacja, młodzież i kultura wspótczesna. Kilka uwag o praktyce pedagogicznej, Katowice 2003.

Opolska-Bielańska A., Nastolatek w mediach, w: Recepcja mediów przez mtodzież i osoby doroste, red. B. Boniecka, A. Granat, Wydawnictwo Uniwersytetu Marii Curie-Skłodowskiej, Lublin 2018.

Orędzie papieża Franciszka na XLIx Światowy Dzień Środków Społecznego Przekazu. Przekaz o rodzinie jako uprzywilejowanym miejscu spotkania w bezinteresownej miłości, http://www.vatican.va/content/francesco/pl/ messages/communications/documents/papafrancesco_20150123_messaggio-comunicazioni-sociali.html (2.01.2020).

Otapowicz D., Sakowicz-Boboryko A., Wyrzykowska-Koda D., Niepetnosprawność a jakość życia rodziny, „Pogranicze. Studia Społeczne” xxviII (2016).

Portal Dzieci są ważne, https://dziecisawazne.pl/rodzic-dziecka-niepelnosprawnego-widzi-wiecej/ (3.01.2020).

Portal Fortune, https://fortune.com/2019/02/05/modern-family-ending-finale-cast-final-season/ (2.01.2020).

Portal z recenzjami rozrywki „Rottentomatoes”, https://www.rottentomatoes.com/tv/speechless/so1/reviews (3.01.2020).

Reklama fundacji, https://www.youtube.com/watch?v=HePADT5Oakk (3.01.2020).

Reklama leku na katar, https://www.youtube.com/watch?v=oMxlyUohluU, (dostęp: 2.01.2020r.).

Reklama mieszanki przypraw, https://www.youtube.com/ watch?v=2uGs7vs7Udo (2.01.2020).

Rodzina, w: Encyklopedia pedagogiczna, red. M. Pomykało, Warszawa 1993. 
„Rzeczpospolita”, https://www.rp.pl/Spoleczenstwo/312019867-Niemcy-policzyli-gejow-i-lesbijki-w-Polsce.html (3.01.2020).

Serwis informacyjny - kampania z okazji Międzynarodowego Dnia Głuchych https://szczecin.tvp.pl/27081774/1830-250916 (3.01.2020).

Starzyńska K., Charakterystyka reklamy w oparciu o jej genezęi cechy, „Zeszyty Naukowe Uniwersytetu Przyrodniczo-Humanistycznego w Siedlcach" (2015) nr 6, s. 276-281.

Stowarzyszenie Dać Pomoc, http://dacpomoc.pl/Grupa-wsparcia.html (2.02.2020).

Struck-Peregończyk M., Wizerunek osób niepetnosprawnych w środkach masowego przekazu - zarys zjawiska, „Kwartalnik Internetowy Komunikacja Społeczna" (2013) nr 4 (8), s. 22-32.

Suchocka A., Królikowska I., Kreowanie tożsamości kulturowej jako wyzwanie XXI wieku, „Colloquium Wydziału Nauk Humanistycznych i społecznych Kwartalnik" (2014) nr 4, s. 73-88.

Sztompka P., Socjologia. Analiza społeczeństwa, Wydawnictwo PLus, Kraków 2002.

Turek A., Media w rodzinie - rodzina w mediach. Wzajemne relacje w aspekcie etycznym, w: Rodzina między praca a ptaca: refleksja nad społeczna myśla encykliki „Laborem exercens” Jana Pawta II, red. R. Kantor, M. Kluz, J. Młyński, Wydawnictwo Naukowe Uniwersytetu Papieskiego Jana Pawła II, Kraków 2016, s. 213-249.

Widerski J., Modele rodziny w reklamach telewizyjnych. Analiza semiotyczna, „Opuscula Sociologica” (2018) nr 23, s. 83-93. 